\title{
Książki, czasopisma i biblioteki w Krakowie i Lwowie w XIX i XX wieku jako przedmiot aktualnych zaiteresowań polskich i ukraińskich ksiegoznawców
}

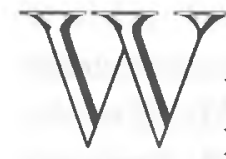

ola zapoznania się z cudzym stanowiskiem jest w nauce - jak wiadomo - pierwszym warunkiem wyzwolenia się od własnych przesądów i uprzedzeń, ale zarazem jest też pierwszym warunkiem prawa domagania się, by nasze stanowisko zostało zrozumiane tak, jak do tego ma prawo stanowisko cudze. Dlatego też cenna jest współpraca - na równych prawach, równej rzetelności. Tak właśnie rozumie się i organizuje się współpracę między księgoznawcami polskimi i ukraińskimi z Krakowa i Lwowa, zapoczątkowaną przed prawie czterema laty konferencją naukową o książkach, czasopismach, bibliotekach tych miast XIX i XX wieku odbytą 3-4 listopada 1994 roku z inicjatywy Katedry Bibliotekoznawstwa i Informacji Naukowej Wyższej Szkoły Pedagogicznej w Krakowie.

Inspiracją dla księgoznawców w tym zakresie były dwie konferencje historyków, zorganizowane przez Wyższą Szkołę Pedagogiczną w Krakowie i Lwowski Uniwersytet im. I. Franki. Tematem ich był Lwów - miasto, społeczeństwo, kultura. Pierwsza z nich odbyła się w Krakowie w listopadzie 1992 roku. Uczestniczyli w niej polscy historycy ze środowisk: krakowskiego, katowickiego, lubelskiego i rzeszowskiego oraz ukrainscy ze Lwowa, Iwano-Frankowska i Kijowa.Wygłoszono na niej 24 referaty. Materiały będące pokłosiem tej konferencji zostały opublikowane w pierwszym tomie pracy Lwów. Miasto - spoleczeństwo - kultura pod red. Henryka W. Żalińskiego i Kazimierza Karolczaka (Kraków 1995).

Druga konferencja odbyła się w maju 1994 roku w Katedrze Historii Ukrainy i Etnografii Uniwersytetu Lwowskiego. Wygłoszono na niej 37 referatów dotyczących dziejów od XIII do XX wieku. Wzięli w niej udział historycy, obok ukraińskich, także polscy z Krakowa, Lublina i Rzeszowa. 
Notatka o konferencji ukazała się w Studiach Historycznych. R. 38: 1995, z. 1, s. 135-136.

Warto tu dodać, że w dniach 29.IV-1.V.1996 roku odbyła się trzecia konferencja. Poprzedziła ją broszurka Lwów. Miasto - spoleczeństwo - kultura. Streszczenie materiałów nadesłanych na konferencję, oprac. K. Karolczak, Kraków 1996. Wygłoszono na niej 51 referatów. Obok sesji plenarnych odbywały się także tematyczne: I. - Społeczeństwo - gospodarka polityka; II. Kultura - nauka; III. Oświata - księgozbiory - sport; IV. Zbiory muzealne i ich upowszechnienie.

Na sesji tematycznej III przedstawiono szereg referatów księgoznawczych.

Dr Edward Różycki wygłosił referat $W$ kręgu zainteresowań czytelniczych Ormian lwowskich. Szkic do dziejów księgozbiorów XVI-XX wieku. Dr Olga Kołosowska z Biblioteki Narodowej m. Lwowa im. W. Stefanika mówiła o starodrukach Biblioteki Poturzyckiej Dzieduszyckich. Prof. Orest Maciuk z Centralnego Państwowego Archiwum Historycznego we Lwowie scharakteryzował zespoły archiwalne Władysława Łozińskiego i Franciszka Jaworskiego, przechowywane w tej placówce. Dr Maria Konopka z katedry Bibliotekoznawstwa i Informacji Naukowej WSP w Krakowie przedstawiła bibliotekę Stowarzyszenia rzemieśników lwowskich „Gwiazda”.

Prof. dr hab. Jerzy Jarowiecki wygłosił referat o konspiracyjnych wydawnictwach we Lwowie 1939-1945.

Autor niniejszej relacji przedstawił wyniki badań Księgozbiór Wiktora Baworowskiego - lwowskiego kolekcjonera i fundatora biblioteki. W podsumowaniu stwierdził, że obok Biblioteki Zakładu Narodowego im. Ossolińskich powstała we Lwowie druga, bez mała nowa pod względem wartości dokumentalnej zbiorów książnica - dzięki kolekcjonerskiej pasji i ofiarności finansowej Baworowskiego. Księgozbiór, jaki został utworzony, był różnorodny pod względem formalnym i treściowym. Obok nowszych druków zgromadzono rękopisy, stare druki, inkunabuły, dyplomy, obrazy. Sąsiadowały obok siebie dzieła literackie i naukowe. Były komplety arcydzieł literatury światowej i rodzimej. Znajdował się przebogaty dział grafiki i ilustracji. Udostępniony za życia fundatora w niewielkim stopniu, a dopiero ogółowi społeczeństwa w naszym wieku stał się źródłem inspiracji i nieocenionym materiałem dla wielu badaczy. W czasie II wojny światowej rozproszony, ale nie zniszczony, w głównej mierze przechowywany w dzisiejszym Lwowie, może nadal służyć uczonym w ich pracy. Zwłaszcza, że obecna sytuacja międzynarodowa temu wyraźnie sprzyja. 
Te wszystkie wystąpienia na konferencji nt. Lwów. Miasto - spoleczeństwo - kultura, dotyczące bibliotek i książek, dowodzą, że tematyka księgoznawcza znalazła się w centrum uwagi organizatorów. Co charakterystyczne - to, że jest ona prezentowana wspólnie przez polskich i ukraińskich uczonych. Nadaje to konferencji szczególny wymiar i tym samym podnosi jej rangę.

Problematyka książek, czasopism i bibliotek Krakowa i Lwowa jest w Katedrze Bibliotekoznawstwa i Informacji Naukowej WSP w Krakowie od dawna systematycznie badana. Rezultatem tego stały się liczne wystąpienia referatowe na konferencjach ogólnoplskich, organizowanych przez Katedrę. Ale nade wszystko badania te były podstawą przewodów doktorskich, także licznych książek i artykułów, których nie sposób tutaj wszystkich wymienić. Oto ważniejsze pozycje i druki zwarte w kolejności chronologicznej: Konspiracyjna prasa w Krakowie w latach okupacji hitlerowskiej Jerzego Jarowieckiego (1980), Prasa krakowska z lat 1795-1830 jako nosnik treści literackich Wandy Krotos (1985), Tanie wydawnictwa literatury pięknej w Galicji $i$ Wolnym Mieście Krakowie w I pol. XIX w. Marii Konopki (1987), Prasa gadzinowa Generalnego Gubernatorstwa (1939-1945) Władysławy Wójcik (1988), Polska prasa konspiracyjna (19391945) i Powstania Warszawskiego w zbiorach Biblioteki Jagielloniskiej Jerzego Jarowieckiego, Ewy Wójcik (1993), Towarzystwa Naukowe w Krakowie w latach 1845-1939 Grażyny Wrony (1994), Literatura popularna dla ludu (na przykładzie Wydawnictwa Ludowego 1882-1920) Józefa Szockiego (1994), Prasa lwowska w dzwudziestoleciu międzywojennym. Próba bibliografii Jerzego Jarowieckiego, Barbary Góry (1994), Problemy kultury w prasie konspiracyjnej w latach 1939-1943 Bożeny Pietrzyk (1995), Czasopisma krakowskie dla dzieci i mlodzieży w dwudziestoleciu międzywojennym Anny Faber-Chojnackiej (1995).

Ten dorobek naukowy, odnoszący się do problematyki książek, czasopism i bibliotek Krakowa i Lwowa XIX i XX wieku, pozwolił na organizowanie konferencji naukowych jej poświęconych.

Pierwsza konferencja odbyła się 7-8 maja 1986 roku i połączona była ze zjazdem absolwentów krakowskich studiów bibliotekoznawczych, spośród któych wywodzili się autorzy niektórych referatów. Poświęcona była głównie problematyce krakowskiej, a tematyka wystapień dotyczyła trzech grup problemów. Pierwszy blok referatów obejmował dzieje bibliotek i domowych księgozbiorów pisarzy i uczonych (R. Jaskuła: Źródla do historii ksiażki i bibliotek $w$ XIX wieku w archiwach krakowskich, J. Zając: Od bi- 
bliotek spolecznych do bibliotek publicznych w Krakowie, H. Kramarz: Biblioteka prof. J. Szujskiego i jej rola $w$ animowaniu życia naukowego w Nowym Saczu, J. Jarowiecki: Księgozbiór J.I. Kraszewskiego). Druga grupa referatów dotyczyłą produkcji książki i jej dystrybucji, edytorstwa i cenzury (M. Zięba: Z dziejów drukarstwa i księgarstwa krakowskiego w latach 18401870, M. Świerczek: Stan drukarstwa krakowskiego w okresie dwudziestolecia międzywojennego. Produkcja poligraficzna, M. Wigluszowa: Produkcja polskiej książki rolniczej w Krakowie $w$ XIX wieku). Jeśli chodzi o trzecią grupę referatów, mowa była w nich o prasie (S. Dziki: Stan badań nad prasq krakowskq, W. Krotos: Wybory literackie w pismach krakowskich z lat 1795-1830, A. Buck: Od „Walki” do „Czarno na biatym”. Uwagi o prasie literackiej mlodych Krakowa w latach 1945-1960).

Ponieważ sesja naukowa odbyła się w trakcie obchodów czterdziestolecia Wyższej Szkoły Pedagogicznej w Krakowie, przeto nie mogło zabraknąć na niej referatów okolicznościowych. Jerzy Jarowiecki mówił o kierunku rozowju badań i kształcenia studentów w Katedrze Bibliotekoznawstwa i Informacji Naukowej Krakowie w latach 1973-1983, zaś W. Magiera o pracach magisterskich powstałych w Samodzielnym Zakładzie Bibliotekoznawstwa WSP w Krakowie w latach 1977-1978.

Druga konferencja odbyła się w dniach 28-29 listopada 1991 roku i była poświęcona problematyce krakowskiej i lwowskiej. Uczestniczyli w niej pracownicy naukowi instytutów i katedr bibliotekoznawstwa i informacji naukowej z całego kraju. Ogółem wygłoszono 24 referaty i komunikaty, ponadto złożono do zbioru materiałów pięć opracowań. Dotyczyły one życia literackiego, ruchu wydawniczego, książek i czasopiśmiennictwa, bibliotek i introligatorstwa Polski południowo-wschodniej. Obok obrad plenarnych odbyły się posiedzenia dwóch sekcji: jedna poświęcona bibliotekom, książkom i wydawnictwom Krakowa i Lwowa w XIX i XX wieku, druga zaś czasopiśmiennictwu.

W opublikowanym po sesji tomie znalazły się referaty:

a) z sekcji pierwszej: R. Jaskuła: Ruch wydawniczy w Galicji w latach 18481863. Problemy badawcze, G. Wrona: Biblioteki i ksiegozbiory krakowskich towarzystw naukowych w latach 1918-1939, M. Pieczonka: Lwowskie firmy wydawnicze w latach 1918-1939. Próba rajestracji ilościowej;

b) w drugiej sekcji: A. Meissner: Polskie czasopisma pedagogiczne Lwowa i Krakowa w okresie autonomii galicyjskiej w latach 1868-1918, A. Misiowa: Zdziejów krakowskiego czasopiśmiennictwa literackiego w latach 1832 1846, G. Gzella: Krakowskie i lwowskie „pisma dla ludu”, M. Konopka: 
„Mrówka" lwowska 1869-1871 Adama Dominika Bartoszewicza, Z. Sokół: Kobiece czasopisma Krakowa i Lwowa w XIX w., A. Herbowski: Wartości wychowawcze lwowskich czasopism dla dzieci i mlodzieży, M. JazowskaGumulska: Treści folklorystyczne w czasopismach dla dzieci i mlodziezy w wieku XIX, E. Skorupka: Na lawie oskarżonych. Konfiskaty prasowe Krakowa w drugiej polowie XIX w., H. Kramarz: Prasa lwowska w czasie I wojny światowej jako przedmiot obserwacji policyjnych, J. Konieczny: Współpraca Witolda Noskowskiego z periodykami na terenie Lwowa i Krakowa i K. Woźniakowski: Namiastka zawodowego życia organizowanego pisarzy polskich w Generalnej Guberni 1939-1945.

Pokłosiem trzeciej konferencji naukowej o książkach, czasopismach i bibliotekach Krakowa i Lwowa XIX i XX wieku, która odbyła się jak wspomniano na wstępie niniejszej informacji, 3-4 listopada 1994 roku, jest publikacja zawierająca wszystkie wystąpienia referentów. Wzięli w niej udział przedstawiciele różnych ośrodków naukowych kraju, a mianowicie uniwersytetów w Krakowie, Warszawie, Wrocławiu, Lublinie, Toruniu, Katowicach, Opolu - wyższych szkół pedagogicznych Krakowa, Kielc, Bydgoszczy, a także, co należy podkreślić z naciskiem - pracownicy naukowi Lwowa.

Goście ukraińscy zaprezentowali ciekawe referaty będące wynikiem ich badań. I tak doc. Orest Maciuk mówił o zasobach Biblioteki Centralnego Państwowego Archiwum Historycznego Ukrainy we Lwowie. Stwierdził, że zawiera ono najbogatszy zbiór dokumentów odzwierciedlających wielowiekową historięUkrainyZachodniej:Dawne pergaminy (najstarszy z1176r.) i ponad milion tomów opowiadajq o życiu narodu, twórczości, kulturze, stosunkach z sasiadami, o walce socjalnej i narodowościowej. Niedawno archiwum uzupetnino dyplomami na korze brzozowej z poczatku XII wieku (najstarszy datowany w 1110). Biblioteka Centralnego Państwowego Archiwum Historycznego Ukrainy we Lwowie powstała z biblioteki byłego miejskiego archiwum $\mathrm{m}$. Lwowa, uzupełniona książami z likwidowanych bibliotek klasztornych, oświatowych zakładów, towarzystw i prywatnych bibliotek znanych historyków-archiwistów: K. Badeckiego, M. Korduby, W. Łozińskiego, A. Prochaski, A. Czołowskiego, później książkami z naukowych bibliotek Uniwersytetu Lwowskiego i Politechniki.

Olga Kołosowska ze Lwowa wygłosiła referat Starodruki biblioteki Wiktora Baworowskiego. Zaprezentowała interesującą publikację pt. Katałog paleotipov iz fondov Lvovskoj naucznoj Biblioteki im. W. Stefanyka AN USSR. (Kijew 1986). Zamieszczono w niej aż 261 druków z pierwszej połowy 
XVI wieku, będących w posiadaniu Baworowskiego. Pochodzą z takich oficyn, jak Hieronima Wietora, Macieja Szarffenberga, Jana Hallera, Floriana Unglera. Referentka z dumą wymieniała, że w „Baworowianum” znajduje się biblia wydana przez pierwszego ukraińskiego drukarza Iwana Fedorowa w Ostrogu w 1581 roku.

Lilia Kowkiel z Państwowego Historyczno-Archeologicznego Muzeum w Grodnie przedstawiła informację o zbiorach książkowych Mniszcha-Potockich w zasobach tego muzeum.

Publikacja jako pokłosie konferencji naukowej z 1994 roku składa się $\mathrm{z}$ dwóch części. W pierwszej zamieszczono referaty dotyczące bibliotek i księgozbiorów oraz ruchu wydawniczego Krakowa i Lwowa XIX i XX wieku. Rozpoczyna ją referat Józefa Szockiego o lwowskich księgozbiorach historycznych, głównie domowych w okresie zaborów. Udało się autorowi zebrać informacje o 143 księgozbiorach domowych. Charakterystyczny jest fakt, że ich właścicielami byli głównie inteligenci i ziemianie. Jolanta Gwoździk przedstawiła rękopisy panien benedyktynek łacińskich w zbiorach Biblioteki im. W. Stefanika we Lwowie. Jej referat dopełnia katalog rękopisów. Maria Konopka pisze o Taniej Wypożyczalni Książek Polskich Adama Dominika Bartoszewicza we Lwowie (1872-1879). Tak scharakteryzował sam Bartoszewicz krąg użytkowników tej Wypożyczalni: Klientela moja skladala się z przedmieszczan, Żydów, żotnierzy a malo bardzo z inteligencji, pomimo że mialem najlepszy wybór ksiażek, ba najnowsze dziela, klientela moja wprawdzie żadala innych dziel: Borna, Dumasa, Kocha itp., ale tego nie było w moim programie. Dorota Wilk przedstawiła informację o bibliotekach polskich we Lwowie w dobie autonomii galicyjskiej. Jerzy Piaskowski jest autorem pracy Ksiqżki na tamt technologii metali wydane w Krakwie i Lwowie w latach 1766-1939. Roman Jaskuła pisze o berlińskich nakładach Karola Forstera na rynku wydawniczym Lwowa w latach 1857-1879. Wreszcie Edward Różycki prezentuje pracę $Z$ dziejów biblioteki parafialnej w Drohobyczu.

Druga część zawiera referaty o periodykach krakowskich i lwowskich. Jerzy Jarowiecki pisze o prasie lwowskiej w dobie popowstaniowej. Grażyna Wrona o krakowskich czasopismach naukowych w latach 1918-1939, Zofia Sokół o krakowskiej prasie kobiecej w latach 1918-1994, zaś Barbara Gierszewska o lwoskich i krakowskich czasopismach filmowych do 1939.

$\mathrm{Z}$ innych referatów o czasopismach, zamieszczonych w prezentowanej tu publikacji, trzeba wymienić Henryki Kramarz: Miesięcznik , Sztuka" (19111913) w stużbie kultury polskiej na kresach, Ludwika Mroczki: Wojenna 
„Pobudka” lwowska 1918-1919, Macieja Kawki: Krakowskie czasopismo jezzykoznawcze „Język Polski” (1913-1994), Alfreda Toczka: Stosunek „Naprzodu" do innych pism politycznych Krakowa i PPS w latach 1919-1934, Jana Bujaka: Jeszcze jedno nieznane polskie czasopismo na Bukowinie, Marka Pieczonki: Wokól lwowskiej i krakowskiej „Chwili” (1906-1913).

Znalazły się w tej części jeszcze takie wypowiedzi, jak: Kalendarze lwowskie w okresie dwudziestolecia międzywojennego Ewy Wójcik, Udzial lwowskich czasopism satyrycznych w tworzeniu mitu lwowskiego batiara Urszuli Jakubowskiej, Jawna dzialalność wydawnicza w okupowanym przez Niemców Lwowie (1941-1944) Krzysztofa Woźniakowskiego, Zagadnienia literackie na lamach krakowskiego „Magazynu Kulturalnego" (1971-1983) Henryka Czubały i wreszcie Kraków w powojennych wędrówkach pisarzy (1945-1949) Jerzego S. Ossowskiego.

W dniach 4-5 listopada 1997 roku odbyła się IV Ogólnoplska Konferencja Naukowa nt. Ksiqżka, czasopisma, biblioteki Krakowa i Lwowa XIX-XX wieku. Uczestniczyli w niej przedstawiciele uniwersytetów w Krakowie, Wrocławiu, Toruniu, Katowicach i Opolu, także wyższych szkół pedagogicznych w Krakowie, Kielcach, Zielonej Góry. Niestety nie przybyli ukraińscy uczeni ze Lwowa, ale przysłali materiały na konferencję. Wygłoszono ogółem 32 referaty. Szczególnie bogato była prezentowana tenatyka lwowska. I tak prof. Anna Aleksiewicz z Uniwersytetu Wrocławskiego scharakteryzowała zbiorowość drukarzy Lwowa w XIX wieku, dr hab. Maria Konopka z WSP w Krakowie mówiła o ruchu księgarsko-wydawniczym Lwowa w latach autonomii, dr hab. Grażyna Gzella z Uniwersytetu Toruńskiego przedstawiła lwowskie inicjatywy książki dla ludu z połowy XIX wieku, prof. Urszula Jakubowska z WSP w Kielcach omówiła Lwów w literaturze pięknej po 1945 roku, dr hab. Danuta Adamczyk z tej samej uczelni przedstawiła lwowskie i krakowskie inicjatywy promocji przekładów polskiej literatury za granicą w początkach $\mathrm{XX}$ wicku.

Wartość opracowań problemów podjętych w prezentowanych wyżej referatach wygłoszonych na konferencjach naukowych a następnie wydrukowanych, jest niewątpliwa. Są one w zasadzie oryginalne i często jedyne, a ponadto odnoszą się do nowych obszarów badawczych, jakimi są Lwów, Galicja Wschodnia, Wileńszczyzna. Stanowią więc interesujący materiał dla wielu bibliotekarzy, księgoznawców, jak w ogóle dla badaczy - tych, którzy nie mieli moźliwości penetrowania tych problemów na tych obszarach. Tym bardziej są godne uwagi, że podejmowane są wspólnie z uczonymi ukraińskimi, ba, nawet białoruskimi, a zatem ustalenia powstałe w wyniku tych 
badań są do zaakceptowania mimo różnic historycznych, nieraz ideologicznych, czy politycznych. Stanowią także dobry start w przyszłość.

\section{的篹}

